\title{
ВЛИЯНИЕ ЦЕОЛИТО-САПРОПЕЛЕВОЙ КОРМОВОЙ ДОБАВКИ НА МОЛОЧНУЮ ПРОДУКТИВНОСТЬ КОБЫЛ В УСЛОВИЯХ ЯКУТИИ
}

A.A. Sidorov

\section{THE EFFECT OF ZEOLITE-SAPROPEL FEED ADDITIVES ON MILK PRODUCTIVITY OF MARES IN THE CONDITIONS OF YAKUTIA}

Сидоров Андрей Андреевич - ст. преп. каф. технологии переработки продуктов животноводства и общественного питания Якутской государственной сельскохозяйственной академии, г. Якутск. E-mail: grig_mf@mail.ru

Цель исследования - определить влияние цеолито-сапропелевой кормовой добавки на молочную продуктивность кобыл в условиях Якутии. Задачи исследования: изучить молочную продуктивность дойных кобыл на фоне использования в их рационах цеолитосапропелевой кормовой добавки; исследовать морфоологический и биохимический состав крови кобыл при включении в их рационы цеолитосапропелевых кормовой добавок. Для проведения опытов было сфрормировано 3 подопытные группы дойных кобыл мегежекской породы. В каждой группе было по 12 голов, подобранных по принципу аналогов. Аналогичность в группах достигнута за счет таких показателей, как возраст, живая масса и уровень продуктивности животных. Условия опытов для всех подопытных животных были одинаковыми за исключением дополнительных цеолито-сапропелевых кормовых добавок в опытных группах. Изучены фииико-химические показатели молока по показателям: массовая доля жира, массовая доля белка, кислотности и плотности. Биохимические анализы были проведены по общепринятым методикам. В canропелях не было выявлено возбудителей болезней. Химический состав сапропеля представлен следующим вещественным и минеральным составом: влага - 23,06 \%; гумус 7,50 \%; азот - 0,45 \%; россрор - 116,46 м2/к2; калий - 614,65 мә/к2; марганеи - 6,61 г/к2; медь - 194,30 ме/к2; цинк - 435,60 ме/к2; железо 370,50 г/ке; кобальт - 78,12 мг/100 2; йод -
Sidorov Andrey Andreevich - Senior Lecturer, Chair of Technology of Processing of Livestock Products and Public Catering, Yakut State Agricultural Academy, Yakutsk.

E-mail: grig_mf@mail.ru

1,60 м2/100 г; селен - 67,77 ме/ке; молибден 31,80 ме/ке; хлориды - 0,59 ме/100 г. Использование в составе рационов цеолитосапропелевой кормовой добавки повлияло на молочную продуктивность кобыл. Так, среднесуточный удой I и II опытных групп был выше контрольной группы на 20,5-26,1 \% соответственно. По содержанию доли жира и белка опытные группы превзошли контрольную на 35,81-49,74 и 13,24 \%, по показателю плотности - на 0,32 и 0,42 \% соответственно. Таким образом, экспериментально доказано повьшение молочной продуктивности кобыл за счет включения в рационы цеолито-сапропелевых кормовых добавок.

Ключевые слова: молочная продуктивность, корма, цеолит, сапропель, кобылы.

The research objective was to define the influence of zeolite-sapropel feed additives on dairy efficiency of mares in the conditions of Yakutia. The research problems were to study dairy efficiency of milk mares while using of zeolite-sapropel feed additives in their diets; to investigate morphological and biochemical composition of mares blood at inclusion in their diets of zeolite-sapropel feed additives. For carrying out the experiments 3 experimental groups of milk mares of megezheksky breed were created. In each group there were up to 12 heads picked up for the principle of analogs. Analogousness in groups was reached at the expense of such indicators as age, live weight and level of efficiency of animals. The conditions of the experi- 
ments for all experimental animals were identical except for additional zeolite-sapropel feed additives in experimental groups. Physical and chemical indicators of milk on indicators were studied: mass fraction of fat, mass fraction of protein, acidity and density. Biochemical analyses were carried out by the standard techniques. In sapropels causative agents of diseases were not revealed. Chemical composition of sapropel was represented by the following material and mineral structure: moisture $23.06 \%$; humus - $7.50 \%$; nitrogen - $0.45 \%$; phosphorus - $116.46 \mathrm{mg} / \mathrm{kg}$; potassium - 614.65 $\mathrm{mg} / \mathrm{kg}$; manganese - $6.61 \mathrm{~g} / \mathrm{kg}$; copper - 194.30 $\mathrm{mg} / \mathrm{kg}$; zinc - $435.60 \mathrm{mg} / \mathrm{kg}$; iron - $370.50 \mathrm{~g} / \mathrm{kg}$; cobalt - $78.12 \mathrm{mg} /$ 100; iodine - $1.60 \mathrm{mg} / 100$; selenium - $67.77 \mathrm{mg} / \mathrm{kg}$; molybdenum - 31.80 $\mathrm{mg} / \mathrm{kg}$; chlorides $-0.59 \mathrm{mg} / 100$. Using as a part of diets of zeolite-sapropel feed additives affected dairy efficiency of mares. So, the average daily yield of milk of the first and second experimental groups was above control group for 20.5-26.1\%, respectively. In the maintenance of the share of fat and protein experimental groups surpassed control for 35.81-49.74 and $13.24 \%$, in density indicator for 0.32 and $0.42 \%$, respectively. Thus, the increase of dairy efficiency of mares due to the inclusion into the diets of zeolite-sapropel feed additives was experimentally proved.

Keywords: dairy efficiency, feed, zeolite, sapropel, mares.

Введение. В условиях Якутии существует дефицит минеральных веществ в растительных кормах, при этом в структуре рационов сельскохозяйственных животных преобладают грубые корма [17]. Все это в совокупности с экстремальными природно-климатическими условиями создает проблему для полноценного кормления сельскохозяйственных животных и как результат - получения рентабельного производства.

Рациональное сбалансированное кормление является основой реализации генетического потенциала животных. При этом особое внимание уделяется полноценному обеспечению рационов питательными и минеральными веществами [2]. Известно, что традиционные корма не могут в полной степени обеспечить организм всеми макро- и микроэлементами [14]. Поэтому в практике кормления животных используют различные нетрадиционные кормовые добавки, такие как сапропели и цеолиты $[1,9]$. Сапропели богаты питательными и минеральными веществами, в состав которых помимо этого входят витамины, фрерменты и аминокислоты [1]. Цеолиты известны своими сорбирующими и ионообменными свойствами, обладают достаточно богатым минеральным составом, включение их в рационы животных способствует улучшению физиологических показателей и повышению продуктивности [16].

Имеются сведения об эффективности кормовых добавок, содержащих в составе цеолит и сапропели, в коневодстве. Проведенные исследования Р.В. Ивановым (2000) по использованию цеолита хонгурин и амидосапропелевой добавки при осенне-зимнем откорме (октябрьноябрь) молодняка лошадей полутора лет в условиях Якутии выявили, что кормовая добавка способствовала повышению приростов живой массы на 15,32 \%, улучшила морфологические и биохимические показатели крови животных [11]. Также имеется информация по испытанию белково-витаминно-минеральной смеси с использованием в составе цеолита в кормлении лошадей в Якутии. Так, добавка к суточному рациону способствовала повышению живой массы молодняка до 17 \% [12]. Использование кормовых добавок способствовало восполнению дефицита в рационе лошадей натрия, фосффора, железа, кобальта и йода $[11,12]$. Аналогичные исследования были проведены в условиях ФАУ МО РФ ЦСКА (г. Москва), исследовано влияние природного клиноптилолита в кормлении лошадей, установлено, что добавки способствовали повышению ффизиологических показателей животных [10].

В Якутии зимний период длится 200-250 дней, температура окружающей среды - от $+38{ }^{\circ} \mathrm{C}$ до $-67,8{ }^{\circ} \mathrm{C}$ (Верхоянский район) и $-71,2{ }^{\circ} \mathrm{C}$ (Оймяконский район), где в растительных кормах существует недостаток минеральных веществ, в частности меди, натрия, фосфрора, кобальта и йода. Поэтому изыскание новых способов повышения продуктивности коневодства представляет научно-практический интерес для сельского хозяйства региона, так как аборигенная лошадь - единственный вид сельскохозяйственных животных, которые пасутся круглогодично и их рацион состоит из подножного корма $[11,12,17]$. 
На территории Республики Саха (Якутия) имеется Сунтарское месторождения цеолитов, запас оценивается в 11,4млн т. Химический состав цеолита Сунтарского месторождения представлен в диаграмме (рис.) [8].

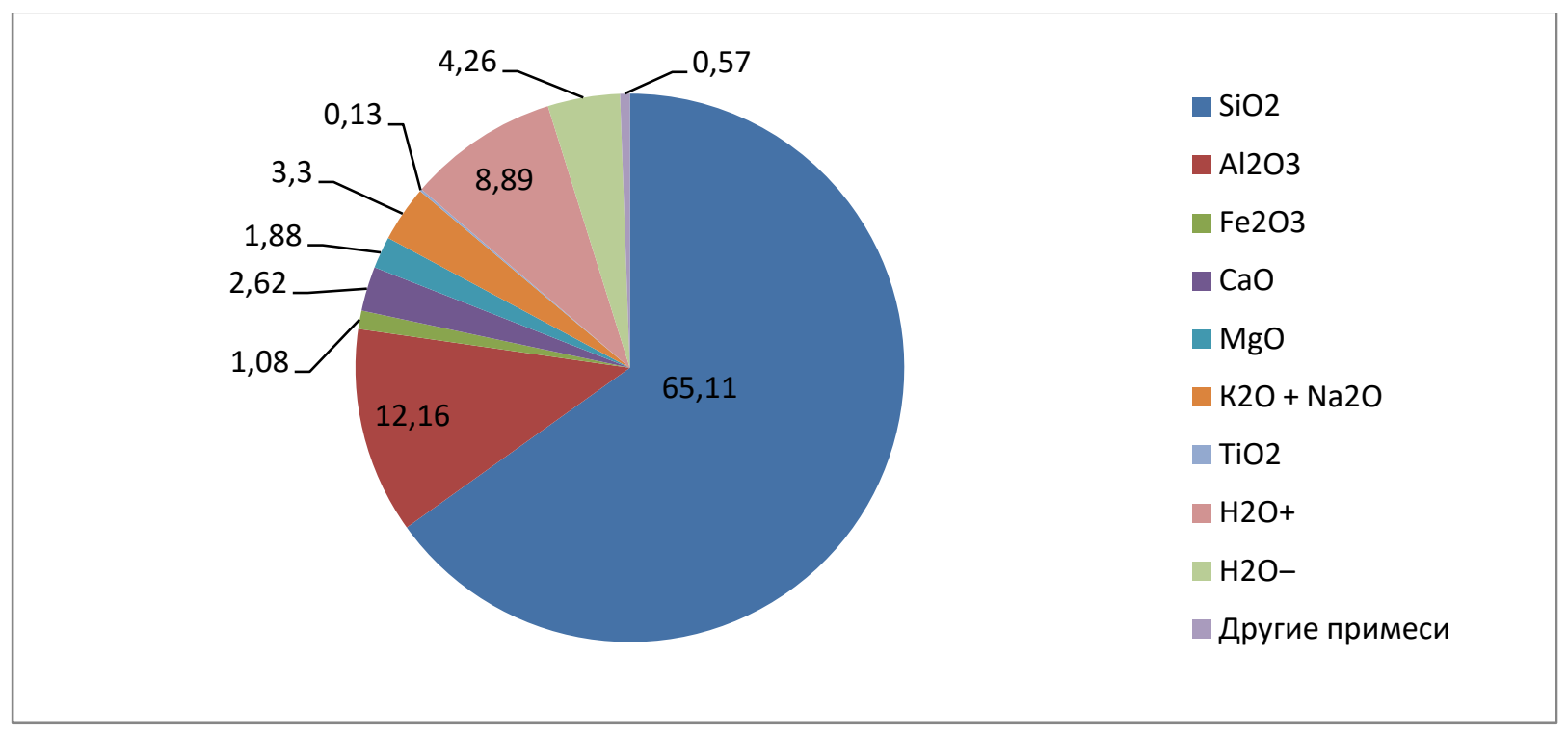

Химический состав цеолита Сунтарского месторождения, \%

В состав цеолита Сунтарского месторождения входит: $\mathrm{SiO}_{2}-65,11 \% ; \mathrm{Al}_{2} \mathrm{O}_{3}-12,16 ; \mathrm{Fe}_{2} \mathrm{O}_{3}-$ 1,08; $\mathrm{CaO}-2,62 ; \mathrm{MgO}-1,88 ; \mathrm{K}_{2} \mathrm{O}+\mathrm{Na}_{2} \mathrm{O}-3,3$; $\mathrm{TiO}_{2}-0,13 ; \mathrm{H}_{2} \mathrm{O}^{+}-8,89 ; \mathrm{H}_{2} \mathrm{O}^{-}-4,26$ и другие примеси - 0,57\%.

Вопросы сбалансированного кормления дойных кобыл в Якутии на сегодняшний день актуальны.

Цель исследования: определить влияние цеолито-сапропелевой кормовой добавки на молочную продуктивность кобыл в условиях Якутии.

В задачи исследования входило:

- изучить молочную продуктивность дойных кобыл на фоне использования в их рационах цеолито-сапропелевой кормовой добавки;

- исследовать морфологический и биохимический состав крови кобыл при включении в их рационы цеолито-сапропелевой кормовой добавки.

Методы исследования. Исследование проведено на базе КФХ «Эйгэ». Научнохозяйственный опыт организован на 3 группах дойных кобыл мегежекской породы. Для прове- дения исследования сформированы три группы подопытных животных по 12 голов методом аналогов. Продолжительность опыта - 120 дней.

Для учета молочной продуктивности кобыл проводили контрольные дойки. Для анализа молока брали 3 подопытных животных с каждой группы. Пробы молока брали в середине опыта (второй месяц лактации). Отбор проб молока - в соотвествии с методикой [7]. Физико-химические показатели молока кобыл изучили по методикам: кислотность - по ГОСТ 3624-92 [3]; массовую долю жира - по ГОСТ 5867-90 [4]; массовую долю белка - по ГОСТ 25179-2014 [5]; плотность - по ГОСТ 3625-84 [6]. Химический состав сапропеля и молока кобыл изучены по общепринятым методикам в лабораториях ФГБОУ ВО «Якутская ГСХА», ФГБНУ Якутский научно-исследовательский институт сельского хозяйства (Якутский НИИСХ) и ГБУ Якутская республиканская ветеринарно-испытательная лаборатория (ЯРВИЛ).

Схема кормления на одну голову лактующей кобылы представлена в таблице 1. 


\section{Схема исследований}

\begin{tabular}{|l|c|}
\hline \multicolumn{1}{|c|}{ Группа кобыл } & Кормовые условия \\
\hline Контрольная группа & ОР \\
\hline І опытная группа & ОР + 360 г ЦСД \\
\hline II опытная группа & ОР + 400 г ЦСД \\
\hline
\end{tabular}

Примечание: ОР - основной рацион; ЦСД - цеолито-сапропелевая добавка.

Компоненты кормовой добавки в указанных пропорциях смешивали и давали вместе с основным рационом. Для приготовления кормовой добавки смешивали компоненты для I опытной группы: цеолит - 160 г (0,4 г/кг ж. м.) с 200 г сапропелем. Для II опытной группы: цеолит 200 г (0,5 г/кг ж.м.) смешивали с 200 г сапропелем. Выбор норм включения цеолита и сапропеля в рацион животных - с учетом рекомендаций $[12,17]$. Условия проведения научного опыта для всех группах кобыл было идентичным за исключением кормовых добавок. Хозяйственный рацион на 1 голову в сутки состоял из 15 кг сена, 4 кг концентрированного корма (овес) и 40 г соли поваренной (табл. 2).

\section{Суточный рацион лактирующих кобыл}

\begin{tabular}{|l|c|c|}
\hline \multicolumn{1}{|c|}{ Химический состав } & $\begin{array}{c}\text { Норма кормления } \\
\text { кобыл }\end{array}$ & Содержится, ед. \\
\hline Сухое вещество, кг & 12 & 13,2 \\
\hline Энергетических кормовых единиц, ЭКЕ & 10,0 & 11,2 \\
\hline Обменной энергии, МДж & 100,4 & 111,8 \\
\hline Переваримый протеин, г & 1004 & 1119 \\
\hline Сырая клетчатка, г & 2160 & 2250 \\
\hline Кальций, г & 60 & 63,1 \\
\hline Фосфрор, г & 42 & 49,7 \\
\hline Магний, г & 15,6 & 16,9 \\
\hline Железо, мг & 960 & 974,1 \\
\hline Медь, мг & 108 & 109,3 \\
\hline Цинк, мг & 360 & 368,2 \\
\hline Кобальт, мг & 4,8 & 4,9 \\
\hline Марганец, мг & 480 & 485,1 \\
\hline Йод, мг & 4,8 & 4,8 \\
\hline Каротин, мг & 180 & 224 \\
\hline
\end{tabular}

Анализ рациона животных показал, что кормление было вполне удовлетворительным, но фактическое содержание питательных и минеральных веществ было ближе к нижним границам нормы кормления [13]. Поэтому введение цеолито-сапропелевых кормовых добавок в состав рационов лактующих кобыл в зимний период обосновано тем, что помимо производства единицы молока организм животных нуждается в достаточном обеспечении питательных и минеральных веществ для поддержания оптимальной жизнедеятельности в условиях резко континентального климата.

Для контроля за физиологическим состоянием кобыл изучили морфобиохимические показатели крови по общепринятой методике. Данные исследования обработаны биометрически по методоке Н.А. Плохинского (1961) [15].

Результаты исследования. Анализ сапропеля не выявил возбудителей болезней в образцах. Химический состав сапропеля, исполь- 
зованного в научно-хозяйственном опыте, представлен в таблице 3.

Таким образом, анализ сапропеля показал, что он содержит в составе десрицитные в растительных кормах минеральные вещества.
Включение цеолито-сапропелевой кормовой добавки в суточный рацион кобыл повлияло на молочную продуктивность (табл. 4).

Химический состав опытного образца сапропеля

\begin{tabular}{|c|c|}
\hline Показатель & Значение \\
\hline Первоначальная влага, \% & 23,06 \\
\hline рН-водное, $\%$ & 10,20 \\
\hline $\mathrm{pH}$-солевое, \% & 9,20 \\
\hline Азот нитратный, мг/100 г & следы \\
\hline Гумус, $\%$ & 7,50 \\
\hline Щелочность, мг/100 г & 0,57 \\
\hline Хлориды, мг/100 г & 0,59 \\
\hline Фосффор, мг/кг & 116,46 \\
\hline Калий, мг/кг & 614,65 \\
\hline Азот общий, \% & 0,45 \\
\hline $\mathrm{Mn}$, г/кг & 6,61 \\
\hline $\mathrm{Cu}, \mathrm{мг} / \mathrm{кг}$ & 194,30 \\
\hline $\mathrm{Zn}, \mathrm{Mг} / \mathrm{K} \Gamma$ & 435,60 \\
\hline $\mathrm{Fe}$, г/кг & 370,50 \\
\hline Со, мг/100 г & 78,12 \\
\hline J, мг/100 г & 1,60 \\
\hline $\mathrm{Se}, \mathrm{Mг} / \mathrm{Kг}$ & 67,77 \\
\hline Mo, Мг/Кг & 31,80 \\
\hline
\end{tabular}

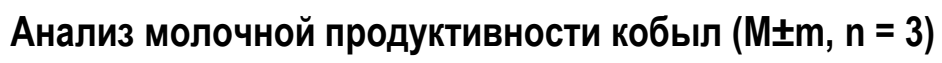

\begin{tabular}{|l|c|c|c|c|}
\hline \multirow{2}{*}{ Показатель } & \multirow{2}{*}{ Норма } & \multicolumn{3}{c|}{ Группа кобыл } \\
\cline { 3 - 5 } & & Контрольная & І опытная & ІІ опытная \\
\hline $\begin{array}{l}\text { Средняя суточная } \\
\text { продуктивность, л }\end{array}$ & - & $4,53 \pm 0,23$ & $5,70 \pm 0,26^{*}$ & $6,13 \pm 0,12^{* *}$ \\
\hline Массовая доля жира, \% & Не менее 1,0 & $0,95 \pm 0,25$ & $1,48 \pm 0,12$ & $1,89 \pm 0,05^{* *}$ \\
\hline Массовая доля белка, \% & Не менее 2,0 & $2,95 \pm 0,20$ & $3,40 \pm 0,06$ & $3,40 \pm 0,10$ \\
\hline Кислотность, ${ }^{\circ}$ Т & Не более 6,0 & $5,00 \pm 0,00$ & $5,33 \pm 0,33$ & $5,67 \pm 0,33$ \\
\hline Плотность, г/см ${ }^{3}$ & Не менее 1032,0 & $1028,33 \pm 2,19$ & $1031,67 \pm 0,88$ & $1032,67 \pm 0,88$ \\
\hline
\end{tabular}

${ }^{*} \mathrm{P}>0,95 ;{ }^{* *} \mathrm{P}>0,99$.

Анализ молочной продуктивности установил, что контрольная группа кобыл уступила по показателям среднесуточного удоя I и || опытным группам животным соответственно на 20,5 и 26,1\%. Контрольная группа уступила незначительно I и II опытным группам на 0,53 и 0,95 \% по показателю жира и 0,45 \% по показателю белка соответ- ственно. По плотности контроль незначительно уступил опытным группам на 0,32 и 0,42 \%. Разница по показателю кислотности не обнаружена.

Для изучения физиологического состояния подопытных кобыл былы исследованы морфологические показатели крови (табл. 5). 


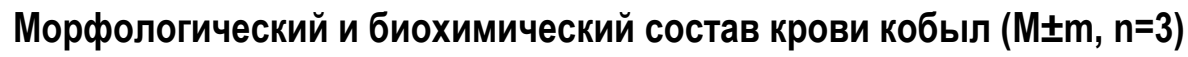

\begin{tabular}{|l|c|c|c|c|}
\hline \multirow{2}{*}{\multicolumn{1}{|c|}{ Показатель }} & \multirow{2}{*}{ Норма } & \multicolumn{3}{|c|}{ Группы кобыл } \\
\cline { 3 - 5 } & & Контрольная & І опытная & І опытная \\
\hline Общий белок, г/л & $55-73$ & $56,33 \pm 1,45$ & $67,67 \pm 1,45^{\star *}$ & $69,67 \pm 1,20^{* *}$ \\
\hline Альбумин, г/л & $27-42$ & $27,00 \pm 0,58$ & $30,67 \pm 2,40$ & $32,67 \pm 2,96$ \\
\hline Глюкоза, ммоль/л & $4,2-7,0$ & $4,26 \pm 0,22$ & $5,06 \pm 0,67$ & $5,87 \pm 0,79$ \\
\hline Холестерин, ммоль/л & $1,3-3,7$ & $2,34 \pm 0,64$ & $2,23 \pm 0,18$ & $2,20 \pm 0,15$ \\
\hline Билирубин общий, мкмоль/л & $9,0-36,0$ & $19,33 \pm 4,67$ & $21,79 \pm 1,55$ & $22,34 \pm 1,46$ \\
\hline Фосфор, ммоль/л & $0,7-1,4$ & $0,85 \pm 0,11$ & $1,03 \pm 0,08$ & $1,25 \pm 0,14$ \\
\hline Кальций, ммоль/л & $2,65-3,25$ & $2,73 \pm 0,18$ & $2,90 \pm 0,06$ & $2,94 \pm 0,09$ \\
\hline Щелочная фросфатаза, ед/л & $102-257$ & $152,00 \pm 52,50$ & $161,67 \pm 18,78$ & $162,00 \pm 25,87$ \\
\hline Глобулин, г/л & $21-38$ & $23,67 \pm 2,19$ & $27,67 \pm 4,18$ & $28,67 \pm 5,24$ \\
\hline Лейкоциты, ×109/л & $5,2-13,9$ & $11,82 \pm 1,12$ & $10,40 \pm 1,44$ & $9,26 \pm 0,47$ \\
\hline Эритроциты, ×1012/л & $6,4-10,0$ & $6,54 \pm 0,25$ & $8,29 \pm 0,60$ & $8,71 \pm 0,91$ \\
\hline Гемоглобин, г/л & $110-170$ & $148,67 \pm 16,90$ & $154,67 \pm 18,12$ & $169,33 \pm 25,10$ \\
\hline
\end{tabular}

Примечание: * $\mathrm{P}>0,95 ;{ }^{* *} \mathrm{P}>0,99$.

Изучение морфологического и биохимического состава крови не выявило отклонений от физиологических норм, что свидетельствует о безвредности кормовых добавок.

Выводы. Данные исследования свидетельствуют, что включение цеолито-сапропелевых кормовых добавок в суточный рацион дойных кобыл повышает их молочную продуктивность на 20,5-26,1 \%, улучшает фризико-химические показатели молока на 35,81-49,74 и 13,24 \% соответственно, не вызывает нарушение обмена веществ.

Таким образом, на основании исследований можно заключить, что использование цеолитосапропелевых кормовых добавок в молочном коневодстве Якутии имеет перспективу.

\section{Литература}

1. Бессонова Н.М., Петрусева Н.С., Алисова Г.А., Ларина Г.В. и др. Эффрективность применения высокомолекулярных веществ из торфа и сапропеля в рационах пантовых оленей Горного Алтая // Вестн. КрасГАУ. 2011. - № 6 (57). - С. 102-106.

2. Голубков А.И. и др. Оптимизация энергопротеинового отношения в рационах нете- лей енисейского типа красно-пестрой породы в сухостойный период и коровпервотелок в фразах раздоя и середины лактации // Вестн. КрасГАУ. - 2013. № 3 (78). - C. 107-116.

3. ГОСТ 3624-92. Молоко и молочные продукты. Титриметрические методы определения кислотности. - М., 1992.

4. ГОСТ 5867-90. Молоко и молочные продукты. Методы определения жира. - М., 1990.

5. ГОСТ 25179-2014. Молоко и молочные продукты. Методы определения массовой доли белка. - М., 2014.

6. ГОСТ 3625-84. Молоко и молочные продукты. Методы определения плотности (с Изменением № 1). - М., 1984.

7. ГОСТ 26809.1-2014. Молоко и молочная продукция. Правила приемки, методы отбора и подготовка проб к анализу. - М., 2014.

8. Егорова А.Д., Рожин В.Н., Филиппова К.Е. Влияние добавки цеолита-хонгурина на свойства камня на основе минеральных вяжущих веществ // Современные наукоемкие технологии. - 2012. - № 9. - С. 62-63. 
9. Жидик И.Ю., Заболотных М.В. Влияние цеолита природного Холинского месторождения на минеральный и витаминный состав мяса кроликов // Вестн. КрасГАУ. 2016. - № 6 (117). - С. 144-148.

10. Зеленченкова А.А., Некрасов Р.В., Чабаев М.Г., С. Tulunay и др. Эфрфективность использования природного клиноптилолита в кормлении лошадей // Зоотехния. - 2018. № 3. - C. 17-21.

11. Иванов Р.В. Научные основы совершенствования технологии кормления и содержания лошадей якутской породы: дис. ... д-ра с.-х. наук. - Якутск, 2000. - 368 с.

12. Иванов Р.В. Научные основы совершенствования технологии кормления и содержания лошадей якутской породы. Ч. 1. Опыты на молодняке. - Новосибирск, 2004. - 200 с.

13. Калашников А.П. Нормы и рационы кормления сельскохозяйственных животных: справочное пособие / под ред. А.П. Калашникова, Н.И. Клейменова, В.Н. Баканова. М.: Агропромиздат, 1985. - 352 с.

14. Морозова Л.А., Миколайчик И.Н., Абилева Г.У., Субботина Н.А. Эфффективность использования микробиологических добавок в рационах стельных сухостойных коров // Вестн. КрасГАУ. - 2016. - № 10 (121). - С. 192-199.

15. Плохинский Н.А. Руководство по биометрии для зоотехников: учеб. пособие. - М.: Колос, 1969. - 328 с.

16. Савкова М.Г., Цыренов С.О., Минина Л.А. Цеолиты Шивыртуйского месторождения в предотвращении отрицательного воздействия микотоксинов в рационе кур-несушек // Вестн. КрасГАУ. - 2010. - № 5 (44). C. 86-90.

17. Черноградская Н.М. Методические рекомендации по использованию нетрадиционных кормовых добавок в животноводстве Якутии. - Якутск: Изд-во ЯГСХА, 2012. - 42 с.

\section{Literatura}

1. Bessonova N.M., Petruseva N.S., Alisova G.A., Larina G.V. i dr. Effektivnost' primeneniya vysokomolekulyarnyh veshchestv iz torfa i sapropelya $\mathrm{V}$ racionah pantovyh olenej
Gornogo Altaya // Vestn. KrasGAU. - 2011. № 6 (57). - S. 102-106.

2. Golubkov A.I. I dr. Optimizaciya energoproteinovogo otnosheniya $v$ racionah netelej enisejskogo tipa krasno-pestroj porody $v$ suhostojnyj period i korov-pervotelok $v$ fazah razdoya i serediny laktacii // Vestn. KrasGAU. - 2013. - № 3 (78). - S. 107-116.

3. GOST 3624-92. Moloko i molochnye produkty. Titrimetricheskie metody opredeleniya kislotnosti. - M., 1992.

4. GOST 5867-90. Moloko i molochnye produkty. Metody opredeleniya zhira. - M., 1990.

5. GOST 25179-2014. Moloko i molochnye produkty. Metody opredeleniya massovoj doli belka. - M., 2014.

6. GOST 3625-84. Moloko i molochnye produkty. Metody opredeleniya plotnosti (s Izmeneniem № 1). - M., 1984.

7. GOST 26809.1-2014. Moloko i molochnaya produkciya. Pravila priemki, metody otbora i podgotovka prob k analizu. - M., 2014.

8. Egorova A.D., Rozhin V.N., Filippova K.E. Vliyanie dobavki ceolita-hongurina na svojstva kamnya na osnove mineral'nyh vyazhushchih veshchestv // Sovremennye naukoemkie tekhnologii. - 2012. - № 9. - S. 62-63.

9. Zhidik I.YU., Zabolotnyh M.V. Vliyanie ceolita prirodnogo Holinskogo mestorozhdeniya na mineral'nyj i vitaminnyj sostav myasa krolikov // Vestn. KrasGAU. - 2016. - № 6 (117). S. 144-148.

10. Zelenchenkova A.A., Nekrasov R.V., Chabaev M.G., C. Tulunay i dr. Effektivnost' ispol'zovaniya prirodnogo klinoptilolita $\mathrm{V}$ kormlenii loshadej // Zootekhniya. - 2018. № 3. - S. 17-21.

11. Ivanov R.V. Nauchnye osnovy sovershenstvovaniya tekhnologii kormleniya i soderzhaniya loshadej yakutskoj porody: dis. ... d-ra s.-h. nauk. - Yakutsk, 2000. - $368 \mathrm{~s}$.

12. Ivanov R.V. Nauchnye osnovy sovershenstvovaniya tekhnologii kormleniya i soderzhaniya loshadej yakutskoj porody. Ch. 1. Opyty na molodnyake. - Novosibirsk, 2004. - $200 \mathrm{~s}$.

13. Kalashnikov A.P. Normy i raciony kormleniya sel'skohozyajstvennyh zhivotnyh: spravochnoe 
posobie / pod red. A.P. Kalashnikova, N.I. Klejmenova, V.N. Bakanova. - M.: Agropromizdat, 1985. - $352 \mathrm{~s}$.

14. Morozova L.A., Mikolajchik I.N., Abileva G.U., Subbotina N.A. Effektivnost' ispol'zovaniya mikrobiologicheskih dobavok $\mathrm{V}$ racionah stel'nyh suhostojnyh korov // Vestn. KrasGAU. 2016. - № 10 (121). - S. 192-199.

15. Plohinskij N.A. Rukovodstvo po biometrii dlya zootekhnikov: ucheb. posobie. - M.: Kolos, 1969. - $328 \mathrm{~s}$.
16. Savkova M.G., Cyrenov S.O., Minina L.A. Ceolity SHivyrtujskogo mestorozhdeniya $v$ predotvrashchenii otricatel'nogo vozdejstviya mikotoksinov v racione kur-nesushek // Vestn. KrasGAU. - 2010. - № 5 (44). - S. 86-90.

17. Chernogradskaya N.M. Metodicheskie rekomendacii po ispol'zovaniyu netradicionnyh kormovyh dobavok v zhivotnovodstve Yakutii. Yakutsk: Izd-vo YAGSKHA, 2012. - 42 s. 